\author{
Abstracta Iranica \\ Abstracta Iranica Revue bibliographique pour le domaine irano-aryen \\ Volume 42-43 | 2021 \\ Comptes rendus des publications de 2019-2020
}

\title{
Christiane Gruber (ed.). The Image Debate: Figural Representation in Islam and Across the World
}

\section{Frantz Chaigne}

\section{(2) OpenEdition}

Journals

Édition électronique

URL : https://journals.openedition.org/abstractairanica/53931

DOI : 10.4000/abstractairanica.53931

ISSN : 1961-960X

Éditeur :

CNRS (UMR 7528 Mondes iraniens et indiens), Éditions de l'IFRI

\section{Référence électronique}

Frantz Chaigne, "Christiane Gruber (ed.). The Image Debate: Figural Representation in Islam and Across the World», Abstracta Iranica [En ligne], Volume 42-43 | 2021, document 2, mis en ligne le 30 décembre 2021, consulté le 02 janvier 2023. URL : http://journals.openedition.org/abstractairanica/53931 ; DOI : https://doi.org/10.4000/abstractairanica.53931

Ce document a été généré automatiquement le 2 janvier 2023.

Tous droits réservés 


\title{
Christiane Gruber (ed.). The Image Debate: Figural Representation in Islam and Across the World
}

\author{
Frantz Chaigne
}

\section{RÉFÉRENCE}

Christiane Gruber (ed.). The Image Debate: Figural Representation in Islam and Across the World. Londres: Ginko, 2019, 240 p., ISBN : 978-1-909942-34-9; 1-909942-34-0.

1 La compréhension du statut de l'image au regard du monde de l'Islam est actuellement d'une importance cruciale en ce début de XXI ${ }^{e}$ siècle et Christiane Gruber a su apporter de précieux outils tant de vulgarisation (articles de journaux, de revues) que scientifiques. Le présent volume, dont elle est éditrice, s'inscrit dans cette dernière catégorie. Il s'articule selon une approche à la fois chronologique et thématique. À une préface de Stefano Carboni et un essai préalable de l'éditrice ("Idols and Figural Images in Islam: A Brief Dive into a Perennial Debate”, p. 9-29) succède une première partie (Pre-Modern Islam) regroupant trois essais : “"Painters will be punished': The Politics of Figural Representation Amongst the Umayyads" (Mika Natif, p. 32-45), "Signs of Silence: Epigraphic Erasure and the Image of the World" (Finbarr Barry Flood, p. 46-71) et enfin "Conditions of Love and Conventions of Representation in the Illustrated Manuscript of Varqa and Gulshah" (Oya Pancaroğlu, p. 72-83). La deuxième partie (Beyond the Islamic World), qui s'attache à montrer les relations avec quelques cultures, rassemble quatre chapitres: "Ichonomachy in Byzantium" (Alicia Walker, p. 87-103), "The Image in Jewish Art" (Steven Fine, p. 104-123), "Religious Imagery and and Image-Making in Pre-Islamic Iran and Central Asia" (Michael Shenkar, p. 124-141) et "Conspicuous Absences: The Avoidance and Uses of Images in Early South-Asian Art" (Robert Decaroli, p. 142-153). On pourra toutefois regretter ici l'absence de références aux images chrétiennes d'Occident. La troisième partie (Modern and Contemporary Islam) rassemble cinq chapitres: "The Figural Image in Islamic Devotional Art in the 
Indian Subcontinent" (Yousuf Saeed, pp. 156-171), “The Shadow Puppet: A South-East Asian Islamic Aesthetic" (James Bennett, p. 172-193), "Enigma and Purpose: Visual Hagiographies of Urban Senegal" (Allen F. Roberts \& Mary Nooters Roberts, p. 194-211), "Figures of Protest in Contemporary Arab and Iranian Art" (Rose Issa, p. 212-226) et "Only for my Shadow: Figuration in Contemporary Iranian Art" (Shiva Balaghié, p. 227-237). Chacun de ces essais apporte un point de vue détaillé sur sa propre thématique. Toutefois, on peut regretter que l'Islam africain ne soit abordé qu'au prisme du Sénégal, occultant le Maghreb et l'Afrique orientale.

\section{AUTEURS}

\section{FRANTZ CHAIGNE}

Chercheur associé, CNRS, Orient \& Méditerranée-«Islam médiéval» 